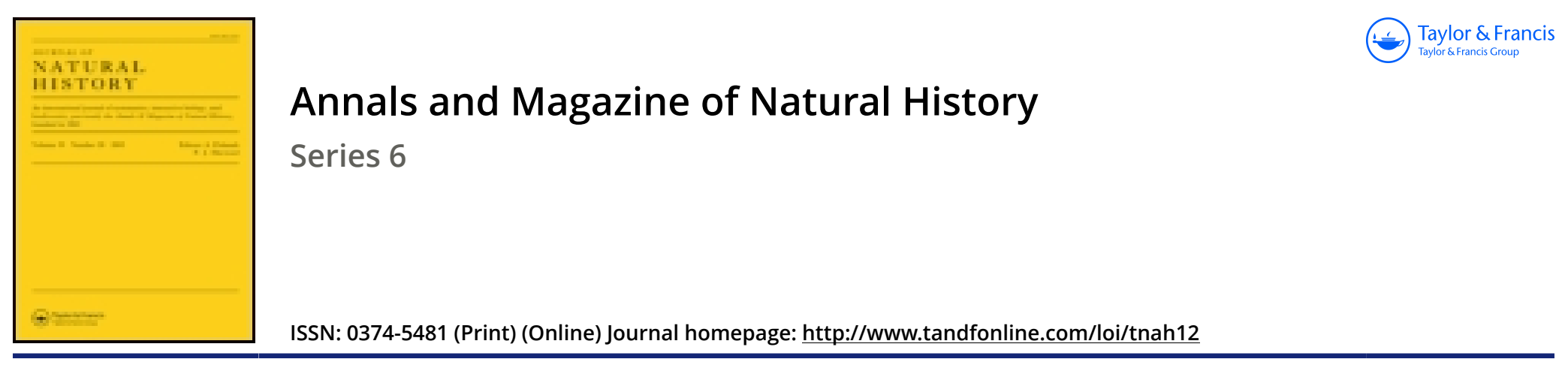

\title{
XXXII.-On the nature of the opaque scarlet spherules found in the chambers and canals of many fossilized foraminifera
}

\section{H.J. Carter F.R.S.}

To cite this article: H.J. Carter F.R.S. (1888) XXXII._On the nature of the opaque scarlet spherules found in the chambers and canals of many fossilized foraminifera, Annals and Magazine of Natural History, 1:4, 264-270, DOI: 10.1080/00222938809460722

To link to this article: http://dx.doi.org/10.1080/00222938809460722

曲 Published online: 12 Oct 2009.

Submit your article to this journal $\pi$

Џll Article views: 4

Q View related articles $₫$ 


\section{Mr. H. J. Carter on the Opaque Scarlet Spherules}

Variety 4, o.- Sinilar to no. 3 , but with the discoidai stripes of the thorax uniting before the middle and continued posteriorly as one broad band to the basal spots with which it unites; the lateral stripe reduced to two very small spots. The red colour of the elytra prevails; the yellow at the apex inconspicuous. Pygidium with an oblong spot in the middle. Abdomen with transverse spots at the sides.

Hab. Koimbatur (M. J. Walhouse, Esq.).

\section{Buprestidæ.}

\section{Chrysochroa alternans, n. sp.}

C. fulgidissimce affinis et similis, obscurior, creberrime fortius punctata, æneo-viridis, subaurata, thorace elytrisque cupreo-rufovittatis.

Long. 17 lin.

Very similar to C. fulgidissima, but less brilliant, with less golden tints ; relatively shorter and more strongly punctured throughout, especially on the disk of the thorax. The elytra are distinctly enlarged at the middle, and are consequently less gradually narrowed to the apex, which is slightly truncate, the sutural angle slightly dentiform. The costre are strongly marked.

Hab. Loo Choo. Brit. Mus.

XXXII.-On the Nature of the Opaque Scarlet Spherules found in the Chambers and Canals of many Fossilized Foraminifera. By H. J. CarTer, F.R.S. \&c.

Is the number of the 'Annals' for last month (p. 172), while describing two new species belonging to the Loftusiida, I had occasion to lay particular stress on the presence in them, as well as in Loftusia persica, of "opaque scarlet spherules," which, although for the most part dispersed through the substance of the fossil, are nevertheless frequently to be seen in the chambers of the foraminiferal tests that have been taken in by each of these species, from which it may fairly be assumed that all had this origin; and these spherules I have further assumed to be representative of the reproductive bodies of the Foraminifera from observations which led to this conclusion (p. 177). Such 
observations, however, it was necessary to summarize briefly on that occasion, as my object then was chiefly to describe the new species of Loftusiida and not the reproductive process of the Foraminifera. But now that the former has been done I propose to return to the latter (so far as the scarlet spherules are concerned) more particularly, and for this purpose it seems best to describe how I came to regard the scarlet spherules as reproductive bodies, and thus recognized them in Loftusia persica.

In limine, then, it should be premised that there is a small portion of Eocene formation on the western side of India, in the neighbourhood of the towns of Surat and Broach, in the province of Guzerat, which is thus described by Medlicott and Blanford in their 'Geology of India,' pt. i. p. 340 (1879), viz. :- "North-west of Surat are thick beds of ferruginous clay, assuming, where exposed, the characteristic brown crust and pseudo-scoriaceous character of laterite, from which they differ in no respect." "These rest on " the traps," and "with them are interstratified beds of gravel or conglomerate containing agate pebbles (the agates being derived from the traps) and limestone, sometimes nearly pure, but more frequently sandy, argillaceous, or ferruginous, and abounding in Nummulites and other fossils. The thickness of the whole can only be roughly estimated as between 500 and 1000 feet." From this formation, about midway between Broach and Surat and the town of Bang, at the village of Wasna or Wansa, that is about 39 miles west-north-west of Broach, the late Major Fulljames picked up some fragments, which he sent to me at the Bombay branch of the Royal Asiatic Society in the year 1853, and of which an account will be found in the 'Journal' of that society (vol. v. p. 624 \&c.).

Some years afterwards, that is in 1861 , I noticed that some of the fragments contained foraminiferal tests in a brilliantly coloured and infiltrated state, to examine which more particularly I broke up a piece, and from it extracted several small specimens of Nunimulites and Orbitoides, which, on being ground down to a smooth surface and thus applied to a "glass slip" by means of Canada balsam, presented under a low power of the microscope sections of unwonted structural clearness and definition, in which the whole of the complicated and delicate parts, both shelly and sarcodic, of the Foraminifera could be seen even better than in the recent specimen. Further, they were more or less charged with the "opaque scarlet spherules" in such situations that they conld not be regarded as anytling but fossilized parts of the recently living animal; nor could any opinion be formed 


\section{Mr. H. J. Carter on the Opaque Scarlet Spherules}

of their nature than that they were the representatives in a mineralized state of its reproductive elements.

I therefore did not hesitate to regard them as such, and so, for confirmation, gave them, in connexion with similar objects in recent specimens of Operculina, as illustrations of the reproductive process, probably in the Foraminifera generally ('Aunals,' 1861, vol. viii. pp. 318 and 319, 325, and 451, and pl. xvii. figs. 12-15 and 1,o). But being then in India I was not aware that Max Schultze had previously noticed and delineated similar bodies in the chambers of recent Rotalice ("Organismus der Polythalamien,' 1854, p. 27), nor that he had shortly after, viz. two years, verified this in a species of Miliola (Müller's 'Archiv,'1856, Nos. 1 and 2, p. 165, Taf. vi. B).

However, here I left the subject, and here it would have remained for myself had not accident thrown in my way the fossil for which I have proposed the name of "Stolicakiella Theobaldi," wherein I was surprised to find, both dispersed through its substance and in the chambers of the enclosed foraminiferal tests themselves, red bodies similar in every respect to those observed in the Wasna specimens, as stated in the communication to which I have alluded. I then sought for the same in my mounted slices of Lnftusia persica, where they were equally abundant; and finally found them again equally plentiful in that species for which I have proposed the name of "Millarella cantabrigiensis" (l.c.). So that, but for these coincidences and this chain of evidence, which an experience of twenty-seven years has thus brought to light, the nature of the Loftusiidæ in this respect might have remained unknown for a considerable time.

It should be noticed here that the only coloured portions in the infiltrated specimens from Wasna are the sarcodiferous cavities and the scarlet spherules, while the shelly parts remain opaque white or transparent, as the case may be; thus the chambers and the intercameral tubes, together with the canal-system, are all more or less filled with bright ochreyellow substance, while the reproductive bodies vary both in point of colour and size, as will be stated hereafter, but are of course most striking by contrast where composed of opaque scarlet or bright rusty-red substance, which renders their presence so peculiarly distinct in these instances that they may be counted under the microscope as easily as peas in the palm of the hand.

Among the specimens of infiltrated Foraminifera from the Eocene of the locality mentioned I am enabled, from the varied sections which they present, to select a series which 
clearly demonstrates the following facts as regards the "scarlet spherules," viz. :-

At the earliest stage in which they can be distinguished they are colourless or slightly opaque, indistinct, and situated singly in the cells of an areolar structure which fills the chamber of the Nummulite. Next they present themselves in a more defined form, of an opaque yellowish-white colour, but still adherent to each other or clustered. In a third stage they are more separated, semitransparent, and of a brown colour, recalling to mind, from their sphericity, when imbedded in clear calcspar, ova in the " hard roe of a herring." Lastly, they present themselves as the "opaque scarlet spherules", above mentioned.

In size the "scarlet spherules" vary from 1-600th in. down to about 1-7000th in. in diameter, which is that of the interior of the intercameral tubes, in which they may be seen to be arranged linearly, by reason of the narrowness of the tubes, while in their larger forms they may also be seen in the chambers and in the vessels of the canal-system, grouped in the former, and linearly arranged if in plurality in the latter, for the same reason. But, wherever they may be, they are always confined to the sarcodiferous cavities of the test, by which they cannot be confounded with any inorganic mineralization.

In number they are most abundant where developed in the areolar tissue of the chambers, when they are of medium size, and each areolar cell appears to be tenanted by only one body; when a little larger and in an opaque scarlet state they are less numerous, but vary much in this respect as well as in size in the chambers where they may be present, unless one or more have passed into one of the vessels of the canalsystem, in which case they are from its narrowness, as before stated, single, or if in plurality linearly disposed; lastly, in their largest form, that is when 1-600th in. in diameter, they are generally single in a chamber where there appears to be nothing else, when they may be seen to be composed of a delicate spherical capsule filled with extremely minute opaque red spherules.

Under such circumstances it is hardly possible to regard these bodies otherwise than as elements of reproduction, even if we had not recent specimens (where of course they are not $r e d$, as this is the effect of mineralization) to compare them with; while they are so abundant in some specimens of these infiltrated Nummulites as to fill not only the large marginal chamber but the whole of the shoulder-like processes of this cavity, which are extended laterally on both sides of 


\section{Mr. H. J. Carter on the Opaque Scarlet Spherules}

the Nummulite up to the summit of the disk, thus according with the extremely prolific nature of these Rhizopodous animals, as indicated by the accumulation of their tests in deposits of bygone ages, as well as those of the present day, in localities where they prevail.

What relation the large opaque scarlet spherule has to the smaller ones I am not able to say, nor is it my business here to inquire. Suffice it to observe that it has not yet been shown that sexual reproduction exists in the Foraminifera, on which this difference in size may be thought to bear, however clear it may be that some of the opaque scarlet bodies in their living and consequently uncoloured state may become new individuals.

Another point worth noticing in the infiltrated Foraminifera of the specimens from the Eocene of Western India to which I have alluded is that they appear not only to have died in the midst of their fecundity, as many of the chambers are literally crammed with these spherules of one colour or another, but from their wonderful state of preservation generally to have undergone the metamorphism of fossilization before their soft parts had passed into dissolution. Sometimes, however, in some parts the red colouring-matter of the scarlet spherules appears to have become diffused, as if the material which takes the red colour in mineralization had previously been in a diffused state.

Although the Foraminifera taken in by Loftusia persica, Stoliczkiella, and Millarella do not present the brilliant coloration generally which renders the different structures so clear and impressive in the Wasna specimens, their forms are rendered recognizable by the presence of the white shelly skeleton or test with the "opaque scarlet spherules" not only in their cameral cavities, but scattered through the mineralized substance of all three fossil species, which, when living, appear to have fed upon them so abundantly that in some parts the structure is rendered absolutely red by their presence, at once evidencing the great fertility of the Foraminifera, as before stated, and the probable object for which they had been taken in by the Loftusia. Neither is the colour influenced in this respect by that of the deposit in which they are found imbedded, for that of Loftusia persica is in grey limestone and that of Millarella cantabrigiensis in chalk.

In the other specimens of Millarella to which I have alluded (footnote, p. 180 loc. cit.) the same kind of foraminiferal detritus is present, but there are no "scarlet spherules," from which it must be inferred that the tests were taken in and fossilized under different circumstanees, that is that they were 
not in a state of fecundity like those containing the scarlet spherules, or that the fossilization failed to render these reproductive bodies red. Thus the presence of these bodies in a red-coloured state is of no specific value.

Moreover, I have observed them scantily here and there in Nummulites contained in a specimen of highly ferruginized yellow deposit from Upper Sind, which is almost entirely composed of the larger forms of the Foraminifera, while for the most part their chambers are charged with the same kind of bodies in a defined but uncoloured or whitish-yellow state, like those above mentioned in the W asna specimens.

Again, when I had discovered them in the Wasna specimens so wonderfully preserved, I was induced to obtain more if possible, so wrote to a friend at Broach to get me some; but all that I received in reply was a packet of Nummulites and Orbitoides, each about the size of a shilling, which certainly possessed the yellow colour of the deposit, but without the presence of any of the opaque scarlet spherules or even any thing beyond the definition of structure observed in Nummulites generally. Were I to seek for specimens brilliantly coloured, similar to those of the village of Wasna, I should be inclined to search for them in the most lateritized parts of the deposit, where they have become brick-red by the profuse diffusion of ferric oxides that characterizes this formation.

In speculating as to the nature of the animal of the Loftusiidæ in the paper to which I have alluded (p. 181), I omitted to notice that at the circumference of the specimen of Millarella cuntabrigiensis the structure indicates that the whole commenced in a reticulated plastic substance, in which the "pits or vacuities" brought to view in the horizontal section represent the interstices, while, as the animal increased in size, this structure inwardly became more compact and then developed the "circular divisions" or inspissations represented in fig. 6 of my illustrations (pl. xiii. l. c.). To which I would add that the so-called "labyrinthic" structure of Loftusia persica may be the fossil representative of a similarly composed solid plasmic structure, although it now looks tubular.

How far these organisms may be allied to typical Foraminifera $I$ am not prepared to say; but of this I am certain, that if such Rhizopodous organisms are to be included among them, they should have a distinct and appropriate diagnosis.

N.B.-To get a clear impression of the composition of a Ann. \& MLag. N. Hist. Ser. 6. Vol. i. 
fossil under the microscope from the surface of a section it should, when not overlaid permanently by Canada balsam and a glass cover, be overlaid for the occasion by a little water and a glass cover; otherwise the ronghness of the dry surface alone, however much it may be polished, will render the examination most imperfect and unsatisfactory.

XXXIII-On Longicorn Coleoptera of the Family Lamiidæ. By Charles J. Gahan, M.A., Assistant in the Zoological Department of the British Museum.

[Plate XVI. figs. 1-5.]

\section{AETHALODES, n. g.}

Head of moderate size and strongly concave between its antennal tubercles; the latter rather short and somewhat distant; front convex, subequilateral. Last joint of palpi ovate-cylindrical. Antennæ scarcely longer than half the body; scape stout, subcylindrical, slightly curved, somewhat expanded at the apex, the latter with a small but distinct cicatrice; fourth joint equal in length to the second and third united, distinctly shorter than the scape.

Prothorax acutely spined at the sides and with large rounded tubercles on the disk.

Elytra oblong, rough, with alternating rows of larger and smaller granules, rounded at the apex, and each elytron having at its base a small median projection.

Legs subequal, the posterior a little longer than the anterior or middle; femora linear; middle tibiæ emarginate.

Pro- and mesosterna simple. Metasternum moderately elongate.

This genus is allied to Trachystola, of which it has the general form, but from which it may be readily distinguished by the short third joint of its antennæ, by the peculiar tuberculation of its thorax, and the less prominent median projection at the base of each elytron.

Athalodes verrucosus, n. sp. (Pl. XVI. fig. 1.)

Niger, squamositate fusca indutus; antennis concoloribus; protherace latcribus acnte spinoso, dorso quinque tuberculis; elytris seriato-granulatis, apieilius rotundatis.

Long. 23-28 mm., lat. $10-11 \mathrm{~mm}$.

Irab. North China. 